\title{
Assessment of Long-Term Hematologic Effects in Differentiated Thyroid Cancer Patients Treated with Radioactive Iodine
}

\author{
Radyoaktif lyotla Tedavi Edilen Diferansiye Tiroid Kanserli Hastalarda Uzun Dönem \\ Hematolojik Etkilerin Değerlendirilmesi
}

\author{
(D) Bircan Sönmez¹, (D) Özlen Bektaş², (D) Nergiz Erkut2, (D) Mehmet Sönmez² \\ ${ }^{1}$ Karadeniz Technical University Faculty of Medicine, Department of Nuclear Medicine, Trabzon, Turkey \\ ${ }^{2}$ Karadeniz Technical University Faculty of Medicine, Department of Hematology, Trabzon, Turkey
}

\section{Abstract}

Objective: Radioactive iodine (RAl) therapy may cause hematologic abnormalities. The aim of this study is to evaluate long-term hematologic effects in differentiated thyroid cancer (DTC) patients after RAI therapy.

Materials and Methods: A total of 1389 patients with DTC who were treated with RAI were retrospectively evaluated. Complete blood cell counts before RAI therapy and at last follow-up and hematologic malignancy development were obtained from the electronic records.

Results: In the long-term analysis, thrombocytopenia and lymphopenia were observed significantly in patients over 60 years of age. Thrombocytopenia was observed more frequently in men. Leukopenia, thrombocytopenia, and lymphopenia were observed significantly with doses of $>175 \mathrm{mCi}$. Thrombocytopenia and lymphopenia were observed significantly with multiple dose administration. Higher frequencies of anemia, thrombocytopenia, leukopenia, neutropenia, and lymphopenia were found in patients with advanced-stage disease. However, patients with advanced-stage disease had higher doses and more multiple doses than patients with early-stage disease. The rate of hematologic malignancy was found to be higher than in the general population.

Conclusion: We suggest that cytopenia be surveyed more carefully in patients older than 60 years of age. The most important risk factor for lower platelets after RAI therapy is male gender. Clinically, the most important predictor for cytopenia is advanced disease stage, which is related to the combined effects of applied high dose activity, multiple dose applications, and high tumor burden.

Keywords: Radioactive iodine, Thyroid cancer, Cytopenia, Hematologic malignancy, Long-term hematologic effects, Thrombocytopenia, Neutropenia

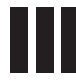

$\ddot{0} z$

Amaç: Radyoaktif iyot (RAi) tedavisi hematolojik anormalliklere yol açabilir. Bu çalışmada, diferansiye tiroid kanserli (DTC) hastalarda RAI tedavisi sonrası uzun dönemli hematolojik etkilerin değerlendirilmesi amaçlanmıştır.

Gereç ve Yöntemler: Bin üç yüz seksen dokuz RAi ile tedavi edilmiş DTC'li hasta retrospektif olarak değerlendirildi. Tedavi öncesi, son takip ve hematolojik malignite geliştikten sonra ölçülen tam kan sayımları elektronik kayıtlardan elde edildi.

Bulgular: Uzun dönemli analizde trombositopeni ve lenfopeni özellikle 60 yaş üstü bireylerde gözlendi. Trombositopeni erkek hastalarda daha sıktı. Lökopeni, trombositopeni ve lenfopeni $>175 \mathrm{mCi}$ dozlarda anlamlı oranda artmıştı. Trombositopeni ve lenfopeni çoklu doz uygulaması olanlarda anlamlı oranda izlendi. Anemi, trombositopeni, lökopeni, nötropeni ve lenfopeni, ileri evre hastalıklı hastalarda daha sıktı. Ancak ileri evre hastalığa sahip hastalar, erken evrelilere göre hem daha yüksek doz hem de çoklu doz tedavi almışlardı. Hematolojik malignite oranı genel popülasyondan daha yüksek oranda idi.

Sonuç: Özellikle 60 yaş üstü hastalar sitopeniler açısından daha yakın izlenmelidir. RAI tedavi sonrası en önemli risk faktörü erkek cinsiyettir. Klinik olarak sitopeniler için en önemli belirleyici ileri evre hastalıktır, ki bu da, daha yüksek doz ve çoklu doz tedavi uygulanmış olmasının ve daha fazla tümör yükünün kombine etkisi ile ilişkilidir.

Anahtar Sözcükler: Radyoaktif iyot, Tiroid kanseri, Sitopeni, Hematolojik malignite, Uzun süreli hematolojik etkiler, Trombositopeni, Nötropeni

๑Copyright 2021 by Turkish Society of Hematology

Turkish Journal of Hematology, Published by Galenos Publishing House

口 Department of Hematology, Trabzon, Turkey

Phone : +905325430575

E-mail : ozlenbektas@hotmail.com ORCID: orcid.org/0000-0002-2670-022X 


\section{Introduction}

Radioactive iodine (RAl) therapy is a commonly used therapeutic option for patients with differentiated thyroid cancer (DTC) for ablation of residual thyroid tissue after thyroidectomy or for the treatment of recurrent and metastatic disease [1]. RAI doses of 30-100 $\mathrm{mCi}$ are used for ablation of residual thyroid tissue. Higher and repeated doses (up to $200 \mathrm{mCi}$ for single doses and $600 \mathrm{mCi}$ for cumulative doses) can be applied for locoregional recurrence or metastatic disease $[1,2,3]$.

After RAI therapy, side effects such as sialadenitis, nasolacrimal duct obstruction, keratoconjunctivitis, amenorrhea, and hematologic abnormalities can be observed in the first few months [4]. Most of these early side effects are usually temporary and have little long-term clinical significance. However, several meta-analyses have reported an increased incidence of second primary malignancies (SPMs) in patients with DTC treated with $\operatorname{RAI}[5,6,7]$.

Temporary anemia, leukopenia, and thrombocytopenia may occur within the first month after a single RAl therapy [8]. Several studies reported improvement in complete blood cell (CBC) counts at 6 months to 1 year after treatment $[9,10]$, while in other studies, the decrease in leukocytes [11], platelets $[8,11,12]$, and lymphocytes [12] persevered.

In our study, we aimed to evaluate the potential long-term effect of RAI on the hematologic system in patients with DTC who received RAl therapy.

\section{Materials and Methods}

A total of 1389 patients who were treated with RAl therapy after total thyroidectomy during 2005-2018 were retrospectively evaluated. Exclusion criteria were i) bone marrow infiltration, ii) receiving external beam radiotherapy and/or chemotherapy at any time, iii) concurrent or pretreatment hematologic malignancies, and iv) patients developing solid cancer. The inclusion criterion was the development of hematologic malignancy after RAl therapy. At the time of the initial treatment, all patients were staged according to the $8^{\text {th }}$ version of the AJCC TNM classification. Each patient was categorized according to receiving single or repeated doses of RAI therapy.

Radioiodine therapy were performed with fixed doses as follows: $\leq 100 \mathrm{mCi}$ (dose I) for remnant ablation, 125-150 mCi (dose II) for those with lymph node metastasis, and $\geq 175 \mathrm{mCi}$ (dose III) for metastatic disease. Levothyroxine (L-T4) was discontinued 4-6 weeks and triiodothyronine (L-T3) was discontinued 2 weeks before RAl therapy. A low-iodine diet for 2 weeks was recommended to all patients before RAI therapy. L-T4 treatment was restarted $48 \mathrm{~h}$ after RAI therapy. Two or more doses were applied to the patients with locoregional recurrence and/or distant metastasis. CBC results before RAI therapy and at the last follow-up and the development of hematologic malignancy were obtained from the electronic records. The criteria for anemia were hemoglobin of $<12 \mathrm{~g} / \mathrm{dL}$ in women and $<13.0 \mathrm{~g} / \mathrm{dL}$ in men, while neutropenia was defined at a level of $<1500 / \mu \mathrm{L}$, leukopenia at $<4000 / \mu \mathrm{L}$, thrombocytopenia at $<150 \times 10^{\%} / \mu \mathrm{L}$, and lymphopenia at $<1000 / \mu \mathrm{L}$.

This study was approved by the Local Ethics Committee of Karadeniz Technical University.

\section{Statistical Analysis}

Data analysis was performed using SPSS 22.0 for Windows. Descriptive statistics were shown as mean \pm standard deviation or median (minimum-maximum) for continuous variables and as number of cases (\%) for categorical variables. Significance between baseline and last follow-up laboratory values was analyzed with the paired samples t-test. Significance between groups was analyzed with the Mann-Whitney $U$ test when the number of independent groups was two and with the Kruskal-Wallis test when the group number was greater than two. If there was a significant difference in the outcome of the Mann-Whitney U or Kruskal-Wallis tests, post hoc tests were used to determine the variables responsible for this significance. Correlation between continuous variables was examined with Spearman's correlation test for non-parametric variables and with Pearson's correlation analysis for parametric variables. Odds ratios were analyzed with binary and multinominal logistic regression. Values of $p<0.05$ were considered statistically significant.

\section{Results}

While 263 patients (18.9\%) were male, 1126 (81.1\%) were female. Mean age was $47.44 \pm 12.52$ (range: $8-82$ ) years. Mean follow-up period and time of last follow-up CBC results was $60.47 \pm 36.60$ (range: 6.67-386.33) months. Baseline characteristics of patients are summarized in Tables 1 and 2.

Upon comparing the differences between baseline and last follow-up hematologic values, a significant decrease was observed in hemoglobin and platelets at the last follow-up $(p=0.000, p=0.012)$. The change between baseline and last follow-up lymphocyte values was significant when patients with hematologic malignancies were excluded $(p=0.002)$ (Table 3).

A negative correlation was found between age and white blood cell (WBC) count, neutrophils, and platelets $(r=-0.094, p=0.000$; $r=-0.093, p=0.001 ; r=-0.126, p=0.000$, respectively) and a positive correlation was found between age and hemoglobin according to the last follow-up laboratory values of the patients $(r=0.076, p=0.004)$. 
It was observed that platelets were significantly lower in patients over 60 years of age $(p<0.001)$. All series in women except platelets and lymphocytes were found to be significantly lower than in men. It was observed that lymphocytes decreased significantly when the dose was increased. Dose 1 with dose 2 and dose 1 with dose 3 made the differences $(p=0.001$ and $p=0.008$, respectively). Hemoglobin, platelets, and lymphocytes also decreased as the stage increased. Stages I and IV for hemoglobin, platelets, and lymphocytes $(p=0.041, p=0.001$, $p=0.006$, respectively) and stages II and IV for hemoglobin $(p=0.046)$ made the differences (Table 4).

\begin{tabular}{|l|l|}
\hline \multicolumn{2}{|l|}{ Table 1. Baseline characteristics of patients. } \\
\hline Patients' characteristics & Mean \pm SD or n (\%) \\
\hline Age & $47.44 \pm 12.5$ \\
\hline$<60$ years & $1150(82.8 \%)$ \\
\hline$\geq 60$ years & $239(17.2 \%)$ \\
\hline Histology & $355(25.6 \%)$ \\
\hline Micropapillary & $954(68.7 \%)$ \\
\hline Papillary & $59(4.2 \%)$ \\
\hline Follicular & $8(0.6 \%)$ \\
\hline Hurthle cell & $6(0.4 \%)$ \\
\hline Poorly differentiated & $5(0.4 \%)$ \\
\hline Follicular and papillary & $1(0.1 \%)$ \\
\hline Hurthle cell and papillary & $1(0.1 \%)$ \\
\hline Hyalinizing trabecular cancer & $1150(82.8 \%)$ \\
\hline Dose I (<100) & $173(12.5 \%)$ \\
\hline Dose II (125-150) & $66(4.8 \%)$ \\
\hline Dose III (>175) & \\
\hline Repeated RAI doses & $1329(95.7 \%)$ \\
\hline 1 & $49(3.5 \%)$ \\
\hline 2 & $8(0.6 \%)$ \\
\hline 3 & $3(0.2 \%)$ \\
\hline 4 & $1224(88.1 \%)$ \\
\hline Staging & $149(10.7 \%)$ \\
\hline I & $16(1.2 \%)$ \\
\hline II & $109(7.8 \%)$ \\
\hline IV & $20.4 \%)$ \\
\hline Lymph node involvement & \\
\hline Metastasis & \\
\hline RAl: Radioactive iodine. & \\
\hline
\end{tabular}

Before treatment, anemia was present in 223 patients (16.1\%), leukopenia in 33 patients (2.4\%), thrombocytopenia in 21 patients (1.5\%), neutropenia in 10 patients (0.7\%), and lymphopenia in 20 patients (1.4\%). When the last follow-up cytopenia status of the patients was examined, it was observed that rates of thrombocytopenia and lymphopenia were significantly higher in patients over 60 years of age ( $p=0.013, p=0.018$, respectively). Males had thrombocytopenia more often than females $(p=0.006)$. Higher doses were a risk factor for leukopenia, thrombocytopenia, and Iymphopenia and the risk increased with RAI of $\geq 175 \mathrm{mCi}$. The frequencies of thrombocytopenia and lymphopenia increased with repeated doses $(p=0.003, p=0.003$, respectively). Cytopenia was more frequent in all 5 series in stage $>$ II (stage IV for this study, since there were no stage III patients in the study group) compared to the earlier stages (Table 5).

Acute myeloid leukemia (AML) developed in $0.2 \%$ cases $(n=3)$, chronic lymphocytic leukemia (CLL) in $0.3 \%(n=4)$, and myelodysplastic syndrome (MDS) in $0.1 \%(n=2)$ (Table 6$)$. The mean time until the development of hematologic malignancy was 38.13 \pm 33.82 (range: 5.46-104.45) months. When hematologic malignancies were evaluated according to their prevalence in the world, the prevalence in our sample was found to be higher than that of the general population.

\section{Discussion}

RAI therapy is one of the standard treatments for DTC. Orally administered RAl diffuses into the circulation through the gastrointestinal tract. The whole body is exposed to highly energetic $\beta$-and $\gamma$-radiation during its transport to, accumulation in, and destruction of thyroid tissue and the urinary excretion of the RAI [13]. Cell renewal, apoptosis, and redistributions of the hematopoietic cells are affected by this radiation [14].

In this study, we have evaluated the long-term hematologic complications of RAI therapy in DTC patients. When the differences between pretreatment and last follow-up laboratory values were examined, it was observed that final hemoglobin and platelets were significantly lower than the baseline levels regardless of gender, applied activity, and number of applications, which suggested that RAI therapy can decrease blood cell levels regardless of cytopenia. There was no significant change between the baseline and last follow-up lymphocyte values

\begin{tabular}{|l|l|l|l|l|l|}
\hline Table 2. Applied doses according to stage. & Dose II & Dose III & $\mathbf{1}$ dose & $\geq 1$ dose \\
\hline Stage I & Dose I & $145(11.8 \%)$ & $38(3.1 \%)$ & $1190(97.2 \%)$ & $34(2.8 \%)$ \\
\hline Stage II & $1041(85.5 \%)$ & $27(18.1 \%)$ & $13(8.7 \%)$ & $135(90.6 \%)$ & $14(9.4 \%)$ \\
\hline Stage III & $109(73.2 \%)$ & NA & NA & NA & NA \\
\hline Stage IV & NA & $1(6.3 \%)$ & $15(93.8 \%)$ & $4(25 \%)$ & $12(75 \%)$ \\
\hline NA: Not applicable. & $0(0 \%)$ & & & \\
\hline
\end{tabular}


when patients with hematologic malignancies were included. We considered that patients with CLL could have increased last follow-up mean lymphocyte counts and repeated the statistical analysis without patients with hematologic malignancies. It was observed that lymphocyte counts were significantly lower when hematologic malignancies were excluded $(p=0.002)$. In the literature, one of the most common complications in long-term follow-up after RAI therapy is a decrease of platelets $[11,15]$. Lymphocytes are the most radiosensitive of all hematologic cells [14]. Granulocytes/monocytes are also more sensitive than erythroid series [13]. However, a decrease in the erythroid series is an expected finding. Molinaro et al. [11] did not observe a change in hemoglobin during 1 year of follow-up, while Schober et al. [15] showed that thrombocytopenia and erythrocytopenia were the most common types of cytopenia in a period of 65 months. Sönmez et al. [8] showed a significant decrease in hemoglobin during 1 year of follow-up.

\begin{tabular}{|c|c|c|c|c|}
\hline & Baseline & Last follow-up & $\begin{array}{l}\text { Changes between baseline } \\
\text { and last follow-up values }\end{array}$ & $\mathbf{p}$ \\
\hline Hemoglobin (g/dL) & $13.50 \pm 1.5(8.4-19.0)$ & $13.3 \pm 1.4(7.9-18.0)$ & $0.18 \pm 1.22$ & $<0.001$ \\
\hline Platelets $\left(10^{3} / \mu \mathrm{L}\right)$ & $260.3 \pm 64.9(16-733)$ & $256.9 \pm 63.0(31-710)$ & $3.42 \pm 5.66$ & 0.012 \\
\hline WBC $\left(10^{3} / \mu \mathrm{L}\right)$ & $6.89 \pm 1.79(0.43-17.75)$ & $6.98 \pm 3.62(1.97-83.02)$ & $-0.10 \pm 3.57$ & 0.284 \\
\hline Neutrophils $\left(10^{3} / \mu \mathrm{L}\right)$ & $4.0 \pm 1.40(0.2-11.97)$ & $3.942 \pm 1.43(0-17.64)$ & $0.06 \pm 1.51$ & 0.141 \\
\hline Lymphocytes $\left(10^{3} / \mu \mathrm{L}\right)$ & $2.26 \pm 0.74(0.17-14.38)$ & $2.24 \pm 1.52(0-45.30)$ & $0.02 \pm 1.33$ & $\begin{array}{l}0.570 \\
0.002^{*}\end{array}$ \\
\hline \multicolumn{4}{|c|}{$\begin{array}{l}\text { RAI: Radioactive iodine; WBC: white blood cell count. } \\
\text { *When hematologic malignancies were excluded, mean baseline lymphocyte value was } 2.25 / \mu \mathrm{L} \text {, mean last follow-up lymphocyte value was } 2.18 / \mu \mathrm{L} \text {, and mean } \\
\text { difference between baseline and last follow-up was } 0.63 \pm 0.76(\mathrm{p}=0.002) \text {. }\end{array}$} & \\
\hline
\end{tabular}

\begin{tabular}{|c|c|c|c|c|c|}
\hline & Hemoglobin $\left(10^{3} / \mu \mathrm{L}\right)$ & WBC $\left(10^{3} / \mu \mathrm{L}\right)$ & Platelets $\left(10^{3} / \mu \mathrm{L}\right)$ & Neutrophils $\left(10^{3} / \mu \mathrm{L}\right)$ & Lymphocytes $\left(10^{3} / \mu \mathrm{L}\right)$ \\
\hline \multicolumn{6}{|l|}{ Age } \\
\hline$<60$ years & $13.34 \pm 1.45$ & $6.98 \pm 3.56$ & $261.46 \pm 63.34$ & $3.95 \pm 1.39$ & $2.2 \pm 0.76$ \\
\hline$\geq 60$ years & $13.28 \pm 1.36$ & $7.02 \pm 3.9$ & $235.02 \pm 57.09$ & $3.9 \pm 1.63$ & $2.42 \pm 3.36$ \\
\hline$p$ & 0.537 & 0.875 & $<0.001$ & 0.636 & 0.305 \\
\hline \multicolumn{6}{|l|}{ Gender } \\
\hline Female & $12.97 \pm 1.20$ & $69.04 \pm 32.09$ & $262.63 \pm 62.34$ & $39.03 \pm 14.48$ & $22.46 \pm 16.50$ \\
\hline Male & $14.85 \pm 1.35$ & $73.48 \pm 50.00$ & $232.38 \pm 60.38$ & $41.06 \pm 13.52$ & $22.05 \pm 0.74$ \\
\hline $\mathrm{p}$ & $<0.001$ & 0.008 & $<0.001$ & 0.007 & 0.948 \\
\hline \multicolumn{6}{|l|}{ Doses } \\
\hline I & $13.36 \pm 1.41$ & $69.76 \pm 31.45$ & $257.49 \pm 60.76$ & $39.23 \pm 13.70$ & $2.88 \pm 1.63$ \\
\hline II & $13.19 \pm 1.52$ & $71.13 \pm 57.74$ & $256.16 \pm 74.07$ & $40.44 \pm 16.91$ & $2.02 \pm 0.62$ \\
\hline III & $12.89 \pm 1.66$ & $65.23 \pm 23.48$ & $231.10 \pm 76.57$ & $40.57 \pm 21.10$ & $18.54 \pm 0.57$ \\
\hline$p$ & 0.239 & 0.188 & 0.332 & 0.734 & $0.001^{a}, 0.008^{b}$ \\
\hline \multicolumn{6}{|c|}{ Repeated doses } \\
\hline 1 & $13.33 \pm 1.42$ & $70.03 \pm 36.72$ & $257.18 \pm 62.41$ & $39.35 \pm 14.11$ & $15.45 \pm 42.43$ \\
\hline$>1$ & $13.35 \pm 1.81$ & $66.67 \pm 21.09$ & $250.83 \pm 76.80$ & $40.90 \pm 18.42$ & $19.07 \pm 6.06$ \\
\hline$p$ & 0.798 & 0.181 & 0.468 & 0.778 & 0.003 \\
\hline \multicolumn{6}{|l|}{ Staging } \\
\hline I & $13.32 \pm 1.44$ & $70.36 \pm 37.93$ & $258.46 \pm 61.71$ & $39.52 \pm 14.12$ & $22.62 \pm 16.01$ \\
\hline II & $13.46 \pm 1.26$ & $66.77 \pm 16.90$ & $249.72 \pm 67.86$ & $38.60 \pm 14.55$ & $21.02 \pm 6.06$ \\
\hline III & NA & NA & NA & NA & NA \\
\hline IV & $13.33 \pm 1.43$ & $62.67 \pm 30.36$ & $205.31 \pm 93.25$ & $39.39 \pm 25.09$ & $16.67 \pm 0.71$ \\
\hline$p$ & $0.041^{c}, 0.046^{d}$ & 0.179 & $0.001^{c}$ & 0.389 & $0.006^{c}$ \\
\hline \multicolumn{6}{|c|}{$\begin{array}{l}\text { WBC: White blood cell count; NA: not applicable. } \\
\text { a: Significance occurred between doses } 1 \text { and } 2 ;{ }^{\text {b: }} \text { significance occurred between doses } 1 \text { and } 3 ; \text { c: significance occurred between stages I and IV; d: significance occurred between } \\
\text { stages II and IV. }\end{array}$} \\
\hline
\end{tabular}




\begin{tabular}{|c|c|c|c|c|c|}
\hline & Anemia & Leukopenia & Thrombocytopenia & Neutropenia & Lymphopenia \\
\hline \multicolumn{6}{|l|}{ Age } \\
\hline$<60$ years & $188(16.3 \%)$ & $21(1.8 \%)$ & $20(1.7 \%)$ & $4(0.3 \%)$ & $13(1.1 \%)$ \\
\hline$\geq 60$ years & $35(14.6 \%)$ & $5(2.1 \%)$ & $11(4.6 \%)$ & $3(1.3 \%)$ & $8(3.3 \%)$ \\
\hline OR (95\% CI) & NS & NS & $0.43(0.19-0.98)$ & NS & $0.41(0.15-1.12)$ \\
\hline $\mathrm{p}$ & NS & NS & 0.013 & NS & 0.018 \\
\hline \multicolumn{6}{|l|}{ Gender } \\
\hline Female & $198(17.6 \%)$ & $21(1.9 \%)$ & $19(1.7 \%)$ & $6(0.5 \%)$ & $21(1.9 \%)$ \\
\hline Male & $25(9.5 \%)$ & $5(1.9 \%)$ & $12(4.6 \%)$ & $1(0.4 \%)$ & $0(0 \%)$ \\
\hline OR (95\% CI) & $0.46(0.32-1.72)$ & NS & $2.79(1.34-5.82)$ & NS & NS \\
\hline$p$ & 0.002 & NS & 0.006 & NS & NS \\
\hline \multicolumn{6}{|l|}{ Doses } \\
\hline 1 & $178(15.5 \%)$ & $18(1.6 \%)$ & $22(1.9 \%)$ & $5(0.4 \%)$ & $14(1.2 \%)$ \\
\hline II & $40(23.1 \%)$ & $4(2.3 \%)$ & $4(2.3 \%)$ & $1(0.6 \%)$ & $3(1.7 \%)$ \\
\hline III & $18(27.3 \%)$ & $4(6.1 \%)$ & $5(7.6 \%)$ & $1(1.5 \%)$ & $4(6.1 \%)$ \\
\hline $\begin{array}{l}\text { OR }(95 \% \mathrm{Cl}) \\
\text { I vs. II }\end{array}$ & NS & NS & NS & NS & NS \\
\hline $\mathrm{p}$ & NS & NS & NS & NS & NS \\
\hline $\begin{array}{l}\text { OR }(95 \% \mathrm{Cl}) \\
\text { I vs. III }\end{array}$ & NS & $4.06(1.33-12.35)$ & $4.20(1.54-11.48)$ & NS & $5.23(1.67-16.37)$ \\
\hline$p$ & NS & $0.014^{\mathrm{a}}$ & $0.005^{\mathrm{a}}$ & NS & $0.004^{a}$ \\
\hline $\begin{array}{l}\text { OR }(95 \% \mathrm{Cl}) \\
\text { II vs. III }\end{array}$ & NS & NS & NS & NS & NS \\
\hline$p$ & NS & NS & NS & NS & NS \\
\hline \multicolumn{6}{|c|}{ Repeated doses } \\
\hline 1 & $220(16.6 \%)$ & $23(1.7 \%)$ & $26(2 \%)$ & $7(0.5 \%)$ & $17(1.3 \%)$ \\
\hline$>1$ & 16 (26.7\%) & $3(5 \%)$ & $5(8.3 \%)$ & $0(0 \%)$ & $4(6.7 \%)$ \\
\hline OR $(95 \% \mathrm{Cl})$ & NS & NS & $0.22(0.80-0.59)$ & NS & $0.18(0.06-0.56)$ \\
\hline$p$ & NS & NS & 0.003 & NS & 0.003 \\
\hline \multicolumn{6}{|l|}{ Staging } \\
\hline I & $206(16.8 \%)$ & $20(1.6 \%)$ & $23(1.9 \%)$ & $5(0.4 \%)$ & $15(1.2 \%)$ \\
\hline II & $23(15.4 \%)$ & $2(1.3 \%)$ & $4(2.7 \%)$ & $0(0 \%)$ & $2(1.3 \%)$ \\
\hline III & NA & NA & NA & NA & NA \\
\hline IV & $7(43.8 \%)$ & $4(25 \%)$ & $4(25 \%)$ & $2(12.5 \%)$ & $4(25 \%)$ \\
\hline $\begin{array}{l}\text { OR }(95 \% \mathrm{Cl}) \\
\text { I vs. II }\end{array}$ & NS & NS & NS & NS & NS \\
\hline$p$ & NS & NS & NS & NS & NS \\
\hline $\begin{array}{l}\text { OR }(95 \% \mathrm{Cl}) \\
\text { I vs. IV }\end{array}$ & $4.10(1.51-11.15)$ & $20.07(5.96-67.62)$ & $17.41(5.22-58.05)$ & $\begin{array}{l}34.83(6.22- \\
194.96) \\
\end{array}$ & $26.87(7.77-92.92$ \\
\hline $\mathrm{P}$ & $0.006^{b}$ & $<0.001^{\mathrm{b}}$ & $<0.001^{\mathrm{b}}$ & $<0.001^{\mathrm{b}}$ & $<0.001^{\mathrm{b}}$ \\
\hline $\begin{array}{l}\text { OR }(95 \% \mathrm{Cl}) \\
\text { II vs. IV }\end{array}$ & $4.74(1.59-14.10)$ & $0.41(0.01-0.25)$ & $0.08(0.02-0.37)$ & NS & $0.41(0.01-0.25)$ \\
\hline $\mathrm{P}$ & $0.005^{c}$ & $<0.001^{\mathrm{c}}$ & $0.001^{\mathrm{c}}$ & NS & $<0.001^{\mathrm{c}}$ \\
\hline
\end{tabular}




\begin{tabular}{|c|c|c|c|}
\hline & AML & CLL & MDS \\
\hline \multicolumn{4}{|l|}{ Age } \\
\hline$<60$ years & 2 & 1 & 2 \\
\hline$\geq 60$ years & 1 & 3 & 0 \\
\hline \multicolumn{4}{|l|}{ Gender } \\
\hline Female & 2 & 3 & 1 \\
\hline Male & 1 & 1 & 1 \\
\hline \multicolumn{4}{|l|}{ Doses } \\
\hline | & 2 & 4 & 1 \\
\hline II & 1 & 0 & 0 \\
\hline III & 0 & 0 & 1 \\
\hline \multicolumn{4}{|c|}{ Repeated doses } \\
\hline 1 & 3 & 4 & 2 \\
\hline$>1$ & 0 & 0 & 0 \\
\hline \multicolumn{4}{|l|}{ Staging } \\
\hline I & 3 & 4 & 1 \\
\hline II & 0 & 0 & 0 \\
\hline III & NA & NA & NA \\
\hline IV & 0 & 0 & 1 \\
\hline \multicolumn{4}{|c|}{$\begin{array}{l}\text { AML: Acute myeloid leukemia; CLL: chronic lymphocytic leukemia; } \\
\text { myelodysplastic syndrome. }\end{array}$} \\
\hline
\end{tabular}

We observed that hemoglobin levels were higher among patients of older age. As age increases, the number of women entering menopause also increases. Considering that women constituted a significant majority of our cases $(81 \%)$, this may explain the hemoglobin increase. We found that platelet counts were significantly lower and rates of clinical thrombocytopenia and lymphopenia were significantly higher in patients over 60 years of age. A decrease in platelets with age after RAI has been previously reported [16]. The decrease in bone marrow reserve with age may explain the thrombocytopenia and lymphopenia.

We found gender-specific differences for certain types of cells. Mean hemoglobin, WBC count, and neutrophils were lower in women than in men. The reason for the difference in hemoglobin is that the normal range of hemoglobin of women is lower than that of men. When the presence of anemia was evaluated, no difference was observed between men and women. However, thrombocytopenia was observed more frequently in men than in women, which indicates that platelets in men are more sensitive to RAl therapy than in women. Prinsen et al. [16] reported more frequent thrombocytopenia in men after RAI. Hu et al. [12] showed in a study with 385 patients that there was a decrease in WBC and lymphocyte counts without gender difference and a greater decrease in platelets in women than in men during the 6-month follow-up. Fewer cases and the shorter follow-up period of that study may be the main reasons for the difference from our results.
We observed that cytopenia occurred more frequently with higher applied activity of RAl. Leukopenia, thrombocytopenia, and lymphopenia occurred more frequently at RAI doses of $\geq 175 \mathrm{mCi}$. A similar result was previously reported about thrombocytopenia and excessive cumulative dose [16]. Padovani et al. [17] showed low hemoglobin and platelets, especially at $>250 \mathrm{mCi}$. When we evaluated the effects of multiple doses, we observed that thrombocytopenia and lymphopenia were more common.

In our study, platelet and lymphocyte counts were found to be lower in patients with stage IV disease. Since there were no patients with stage III in our study, an evaluation could not be performed with that stage. Additionally, as the stage increased, an increase in the frequency of cytopenia was detected in all series. However, it must be noted that advanced-stage patients received higher dose activities and more multiple-dose therapy. It is known that after RAl treatment, the blood RAl concentration shows a diphasic course. In the first 24-48 $\mathrm{h}$, a rapid decrease in inorganic ${ }^{131} \mathrm{I}$ in the blood is observed due to rapid clearance by the kidneys, functional tumor tissue, and remaining thyroid tissue. In the next 2-10 days, a protein-bound ${ }^{131}$ l peak is observed due to release by residual thyroid tissue and/or functional tumor tissue. This can cause RAl to be carried in the body for days [18]. Therefore, higher tumor burden may cause large amounts of RAI to be released into the circulation with a long duration of stay and, as a result, increased bone marrow toxicity may occur. It has been reported that thrombocytopenia is observed more frequently in individuals with large tumor masses [16]. The strongest results in our study were obtained for disease stage and cytopenia. We suggest that the clinical effect of advanced disease stage on cytopenia was due to the combined effect of three factors: higher applied activity, multiple RAI administration, and higher tumor burden.

The incidence of AML is $1.6-2.8$ cases per 100,000 in men and 1.0-2.2 cases per 100,000 in women [19], and the incidence of CLL is approximately 4.2 cases per 100,000 people in the world population [20]. Acute and chronic leukemias have been reported after RAl therapy $[18,21]$. The incidence of leukemia increases with $>600 \mathrm{mCi}$ activity, $>45 \mathrm{~Gy}$, and treatment with short intervals $[11,22]$. Leukemia has been reported very rarely at $<300 \mathrm{mCi}$ activity [11]. Cumulative dose was reported to be the strongest risk factor for leukemia [22,23], aplastic anemia, and MDS [23]. When hematologic malignancies were evaluated according to their incidence in the world, the incidence in our sample was found to be higher than that of the general population. Regarding hematologic malignancies, no relationship was observed with age; furthermore, diagnoses of MDS, AML, and CLL were more frequent in the low-dose RAI group including single dose administration and early-stage disease. We did not observe the reported risk factors for hematologic malignancies in our patient group. Although 
RAI is known to be a risk factor for leukemia, SPMs cannot be ruled out. Karaköse et al. [24] detected 70 SPMs in 1196 patients with thyroid cancer. Thirty-two of them were diagnosed with a second malignancy after thyroid cancer and 38 of them were diagnosed with another malignancy before thyroid cancer. RAI treatment was given to 25 patients in each group. SPM independent of RAI was detected in 45 patients (3.8\%) [24]. The incidence of the malignancy in Turkey is $0.2 \%$. As to be expected, it was reported that the prevalence of SPM was increased by 20 times in patients with thyroid cancer [24]. Silva-Vieira et al. [25] detected SPMs in $4.8 \%$ of patients with thyroid cancer who did not receive RAI treatment. The risk of leukemia is higher in patients with thyroid cancer, and especially in those treated with RAI. The 5- to 10-year absolute leukemia development risk is $0.23 \%-0.26 \%$ in patients with thyroid cancer treated with RAI [26]. The results of our study are similar as the AML rate was $0.22 \%$ and CLL was $0.28 \%$ in patients receiving RAI.

\section{Study Limitations}

The strengths of this study are the long follow-up periods and the large number of cases. The main limitation of our study is its retrospective nature. As a result, we could not evaluate whether the patients were using drugs that would affect hematologic parameters or if they had a disease other than malignancy affecting hematologic parameters during laboratory testing, or menopause status in women. Additionally, patients' cytopenia status could not be evaluated by peripheral blood smear.

\section{Conclusion}

Thrombocytopenia and lymphopenia were observed more frequently in patients older than 60 years of age and we suggest that patients of this age group who receive RAI should be surveyed particularly more carefully for these types of cytopenia. We also observed that higher doses of RAl therapy, multiple doses of RAI administration, and higher tumor burden may cause $\mathrm{CBC}$ abnormalities and cytopenia. The most important risk factor for lower platelet counts after RAI therapy was male gender. Clinically, the most important predictor for cytopenia is advanced disease stage, which is related to the combined effects of applied high-dose activity, multiple dose applications, and high tumor burden.

\section{Ethics}

Ethics Committee Approval: This study was approved by the Local Ethics Committee of Karadeniz Technical University.

\section{Authorship Contributions}

Data Collection or Processing: B.S.; Analysis or Interpretation: Ö.B., N.E., M.S.; Writing: Ö.B.

Conflict of Interest: No conflict of interest was declared by the authors.
Financial Disclosure: The authors declared that this study received no financial support.

\section{References}

1. Haugen BR, Alexander EK, Bible KC, Doherty GM, Mandel SH, Nikiforov YE, Pacini F, Randolph GW, Sawka AM, Schlumberger M, Schuff KG, Sherman SI, Sosa JA, Steward DL, Tuttle RM, Wartofsky L. 2015 American Thyroid Association management guidelines for adult patients with thyroid nodules and differentiated thyroid cancer: the American Thyroid Association Guidelines Task Force on Thyroid Nodules and Differentiated Thyroid Cancer. Thyroid 2016;26:1-133.

2. Andresen NS, Buatti JM, Tewfik HH, Pagedar NA, Anderson CM, Watkins JM. Radioiodine ablation following thyroidectomy for differentiated thyroid cancer: literature review of utility, dose, and toxicity. Eur Thyroid J 2017;64:187-196.

3. Silberstein EB, Alavi A, Balon HR, Clarke SE, Divgi C, Gelfand MJ, Goldsmith SJ, Jadvar H, Marcus CS, Martin WH, Parker JA, Royal HD, Sarkar SD, Stabin $M$, Waxman AD.The SNMMI practice guideline for therapy of thyroid disease with 131। 3.0. J Nucl Med 2012;53:1633-1651.

4. Fard-Esfahani A, Emami-Ardekani A, Fallahi B, Fard-Esfahani P, Beiki D, Hassanzadeh-Rad A, Eftekhari M. Adverse effects of radioactive iodine-131 treatment for differentiated thyroid carcinoma. Nucl Med Comm 2014;35:808-817.

5. Rubino C, de Vathaire F, Dottorini ME, Hall P, Schvartz C, Couette JE, Dondon MG, Abbas MT, Langlois $C$, Schlumberger M. Second primary malignancies in thyroid cancer patients. Br J Cancer 2003;89:1638-1644.

6. Zhang $\mathrm{Y}$, Liang J, Li H, Cong $\mathrm{H}$, Lin $\mathrm{Y}$. Risk of second primary breast cancer after radioactive iodine treatment in thyroid cancer: a systematic review and meta-analysis. Nucl Med Commun 2016;37:110-115.

7. Sawka AM, Thabane L, Parlea L, Ibrahim-Zada I, Tsang RW, Brierley JD, Straus $S$, Ezzat $S$, Goldstein DP. Second primary malignancy risk after radioactive iodine treatment for thyroid cancer: a systematic review and meta-analysis. Thyroid 2009;19:451-457.

8. Sönmez B, Doğan İ, Yavruoğlu C, Can G, Sönmez M. The changes of complete blood count in the thyroid cancer patients treated with the radioactive iodine ablation therapy. Turk J Hematol 2010;27:269-274.

9. Alexander C, Bader JB, Schaefer A, Finke C, Kirsch CM. Intermediate and long term side effects of high-dose radioiodine therapy for thyroid carcinoma. J Nucl Med 1998;39:1551-1554.

10. Yi W, Kim BH, Kim M, Ryang SR, Jang MH, Kim JM, Kim EH, Jeon YK, Kim SS, Kim IJ. Short-term bone marrow suppression in differentiated thyroid cancer patients after radioactive iodine treatment. Endocr J 2020;67:1193-1198.

11. Molinaro E, Leboeuf R, Shue B, Martorella AJ, Fleisher M, Larson S, Tuttle RM. Mild decreases in white blood cell and platelet counts are present one year after radioactive iodine remnant ablation. Thyroid 2009;19:1035-1041.

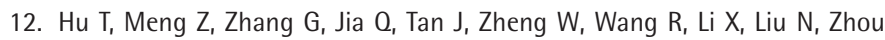
$P$, Upadhyaya A. Influence of the first radioactive iodine ablation on peripheral complete blood count in patients with differentiated thyroid cancer. Medicine 2016;95:35.

13. Monzen S, Mariya $Y$, Wojcik A, Kawamura C, Nakamura A, Chiba M, Hosoda M, Takai Y. Predictive factors of cytotoxic damage in radioactive iodine treatment of differentiated thyroid cancer patients. Mol Clin Oncol 2015;3:692-698.

14. Dainiak D. Hematologic consequences of exposure to ionizing radiation. Exp Hematol 2002;30:513-528.

15. Schober 0 , Günter $H H$, Schwarzrock $R$, Hundeshagen $H$. Long-term hematologic changes caused by radioiodine treatment of thyroid cancer. I. Peripheral blood changes. Strahlenther Onkol 1987;163:464-474.

16. Prinsen HT, Hesselink ENK, Brouwers AH, Plukker JTM, Sluiter WJ, van der Horst-Schrivers ANA, van Imhoff GW, Links TP. Bone marrow function 
after 131 therapy in patients with differentiated thyroid carcinoma. J Clin Endocrinol Metab 2015;100:3911-3917.

17. Padovani RP, Tuttle RM, Grewal R, Larson SM, Boucai L. Complete blood counts are frequently abnormal 1 year after dosimetry-guided radioactive iodine therapy for metastatic thyroid cancer. Endocr Pract 2014;20:213220

18. Keldsen N, Mortensen BT, Hansen HS. Haematological effects from radioiodine treatment of thyroid carcinoma. Acta Oncol 1990;29:10351039.

19. Miranda-Filho A, Pineros M, Ferlay J, Soerjomataram I, Monnereau A, Bray F. Epidemiological patterns of leukaemia in 184 countries: a populationbased study. Lancet Haematol 2018;5:e14-e24.

20. Combest AJ, Danford RC, Andrews ER, Simmons A, McAtee P, Reitsma DJ. Overview of the recent developments in chronic lymphocytic leukemia, part 1. J Hematol Oncol Pharm 2016;6:54-56.

21. Alsaud A, Mohamed S, Yassin MA, Ashour A, Obeidat K, Azrieh B. Acute myeloid leukemia after low-dose radioiodine therapy for papillary thyroid carcinoma. Case Rep Oncol 2020;13:207-211.
22. Albano $D$, Bertagna $F$, Panarotto $M B$, Giubbini R. Early and late adverse effects of radioiodine for pediatric differentiated thyroid cancer. Pediatr Blood Cancer 2017;64:e26595.

23. Probst $\mathrm{S}$, Abikhzer $\mathrm{G}$, Chaussé $\mathrm{G}$, Tamilia M. I-131 radiation-induced myelosuppression in differentiated thyroid cancer therapy. Mol Imaging Radionucl Ther 2018;27:84-87.

24. Karaköse $M$, Çordan I, Can $M$, Kocabaş $M$, Kulaksızoğlu M, Karakurt F. Incidence of second primary malignancies in patients with thyroid cancer in the Turkish population. Turk J Med Sci 2019;49:1529-1533.

25. Silva-Vieira M, Carrilho Vaz S, Esteves S, Ferreira TC, Limbert E, Salgado $\mathrm{L}$, Leite V. Second primary cancer in patients with differentiated thyroid cancer: does radioiodine play a role? Thyroid 2017;27:1068-1076.

26. Sawka AM, Thabane L, Parlea L, Ibrahim-Zada I, Tsang RW, Brierley JD, Straus $S$, Ezzat $S$, Goldstein DP. Second primary malignancy risk after radioactive iodine treatment for thyroid cancer: a systematic review and meta-analysis. Thyroid 2009;19:451-457. 